\title{
Formation of Creative Competence of Future Teachers in The Process of Teaching Mathematics based on Special Tasks
}

\author{
Makhmudova Dilfuza Melievna, Rustamova Nodira Rustamovna, Akbarova Nigora \\ Alimdjanovna, Reymbaeva Sanabar Rejepbaevna
}

\begin{abstract}
This article was written with the aim of creating the creative competence of future teachers in the process of teaching mathematics based on special tasks. The following tasks are considered in the article: how to concretize the essence and structure of the concept "creative competence of the future teacher", determine the criteria and levels of its formation; substantiate and formulate pedagogical conditions for the formation of creative competence of future teachers in teaching mathematics; to develop a methodological model for the formation of creative competence of future teachers in the process of teaching mathematics; create mathematical tasks that contribute to the formation of creative competence of future teachers in the process of their mathematical preparation; create a diagnostic complex to determine and evaluate the level of formation of creative competence of future teachers; to develop a methodology for the formation of future creative competencies in the learning process, the substantive basis of which is a complex of creatively-oriented mathematical tasks, focused on the implementation of the created model; experimentally confirm the effectiveness of the developed methodology for the formation of creative competence of future teachers in the process of teaching mathematics. The article analyzes the basic concepts "competence", "creativity", "creative competence".
\end{abstract}

Keywords: problematic teaching, creative technologies, special tasks, mathematic teaching, interactive ways of teaching.

\section{INTRODUCTION}

The current stage of development of society is characterized by actively ongoing processes of modernization, the most important factor for the success of which is a person focused on creative activity, capable of self-improvement and self-development. The need for creative development of an individual is mentioned in a

Revised Manuscript Received on December 30, 2019.

* Correspondence Author

D.M.Makhmudova*, Faculty of Social Science, Chair of Education, The National University of Uzbekistan after named Mirzo Ulugbek, Tashkent, Uzbekistan

N.R.Rustamova, Chair of General Education, Tashkent State Pedagogical University named after Nizami, Tashkent city, Uzbekistan.

N.A.Akbarova, Faculty of Physics, Chair of Photonics, The National University of Uzbekistan after named Mirzo Ulugbek, Tashkent, Uzbekistan.

S.R.Reymbaeva, Faculty of Physics, Chair of Photonics, The National University of Uzbekistan after named Mirzo Ulugbek, Tashkent, Uzbekistan.

(C) The Authors. Published by Blue Eyes Intelligence Engineering and Sciences Publication (BEIESP). This is an open access article under the CC BY-NC-ND license (http://creativecommons.org/licenses/by-nc-nd/4.0/) number of regulatory documents of the Republic of Uzbekistan. The Decree "On the Strategy for the Further Development of the Republic of Uzbekistan" defines the priority task of "further improving the system of continuing education, increasing the availability of quality educational services" [13]. And in the field of education, extensive reforms will be carried out.

Recognizing the undoubted theoretical and practical significance of the work done, it should be noted that the methodological foundations of the process of teaching mathematics are insufficiently developed, aimed at creating the creative competence of students of a pedagogical university. This fact allows us to identify the following contradictions in the study area:

- at the socio-pedagogical level: between the need of modern society for teachers with creative competence, ready to solve non-standard professional problems using the mathematical apparatus, and the lack of this need in the traditional system of teaching mathematics to future teachers;

- at the scientific and pedagogical level: between sufficient development in psychology and pedagogy of the main provisions for the development of students' creativity and poor knowledge of the methodological aspects of their implementation in the process of teaching mathematics to future teachers;

- at the scientific and methodological level: between the relevance of the formation of creative competence of future teachers in the process of teaching mathematics and the lack of a theoretically sound methodology for the formation of this competency in the process of teaching mathematics.

The highlighted contradictions identified the research problem, which consists in finding the answer to the question: how in the process of teaching mathematics at a university to carry out the formation of creative competence of future teachers?

The relevance and insufficient elaboration of the problem served as the basis for choosing the research topic: "The formation of creative competence of future teachers in the process of teaching mathematics based on special tasks".

\section{METHODOLOGY}

The main idea of the study is to use a set of creatively-oriented mathematical tasks for the formation of creative competence of future teachers in the process of teaching mathematics. 
The purpose of the study: theoretical justification, development and experimental verification of the effectiveness of the methodology for the formation of creative competence of future teachers in the process of teaching mathematics based on a special set of tasks.

The object of study is the process of teaching mathematics to future teachers at a university.

The subject of the study is the formation of creative competence of future teachers in the process of teaching mathematics.

In accordance with the object, subject and purpose of the study, a hypothesis is defined: the methodology for the formation of creative competence of future teachers in the process of teaching mathematics will be effective if:

- the essence and content of the creative competence of future teachers are concretized, its structure is defined and componentwise described, the criteria and levels of its formation are substantiated;

- pedagogical conditions for the formation of creative competence of future teachers in teaching mathematics are identified;

- a model for the formation of creative competence of future teachers in the process of teaching mathematics was developed;

- a complex of mathematical tasks has been created that contributes to the formation of creative competence of future teachers in the process of their mathematical preparation;

- a methodology has been developed for the formation of creative competence of future teachers, the substantive basis of which is the created mathematical tasks;

- created a diagnostic complex to determine and evaluate the level of formation of creative competence of future teachers.

To achieve the goal of the study in accordance with the hypothesis put forward during the work, the following tasks were solved:

- specify the essence and structure of the concept of "creative competence of the future teacher", determine the criteria and levels of its formation;

- substantiate and formulate pedagogical conditions for the formation of creative competence of future teachers in teaching mathematics;

- to develop a methodological model for the formation of creative competence of future teachers in the process of teaching mathematics;

- to create a complex of mathematical tasks that contributes to the formation of creative competence of future teachers in the process of their mathematical preparation;

- create a diagnostic complex to determine and evaluate the level of formation of creative competence of future teachers;

- to develop a methodology for the formation of creative competence of future teachers in the process of teaching mathematics, the substantive basis of which is a complex of creatively-oriented mathematical tasks focused on the implementation of the created model;

- experimentally confirm the effectiveness of the developed methodology for the formation of creative competence of future teachers in the process of teaching mathematics.

The methodological basis of the research was:
- a systematic approach - which allowed us to consider the formation of creative competence of future teachers in the process of teaching mathematics as a component of the system of formation of professional competence of future teachers at a university;

- activity approach - determining the priority of active technologies for the formation of creative competence of future teachers in the process of teaching mathematics;

- a personality-oriented approach to learning, which implies taking into account the individual characteristics of students and considering them as active subjects in the process of forming creative competence in teaching mathematics;

- a competency-based approach to learning, according to which the requirements for the results of the formation of creative competence of future teachers in the process of teaching mathematics are described.

The theoretical basis of the study was the modern conceptual provisions for the development of creative personality traits and creative competence, the concept of teaching mathematics at a university and its focus on the development of creative personality traits.

The following research methods were used to test the hypothesis and solve the problems posed: general theoretical (study and analysis of normative documentation, theoretical and methodological analysis of psychological, pedagogical and scientific-methodical literature on the research problem; modeling); empirical (observation, questionnaire, testing, pedagogical experiment, method of expert assessments, self-esteem); statistical (methods of measuring and mathematical processing of experimental data (Fisher's $\varphi^{*}$ criterion, Student's t-test, Kolmogorov's criterion), their quantitative and qualitative analysis).

\section{LITERATURE SURVEY}

Several scientific studies have been carried out in the republic of foreign countries aimed at creating the creative competence of future teachers in the process of teaching mathematics based on special tasks.

The theoretical, methodological and methodological foundations for improving the content of education with the help of problem tasks are reflected in scientific research: Zh. Ikromov [5], D.I. Yunusova [14], B.S. Abdullaeva [1], M. Sh. Mamatov [8], D.M. Makhmudova [7], S. Alikhonov [2]; students have problems of developing independent creative activity through the introduction of information and communication technologies in education: N.R. Rustamova [11], T. Tulaganov [12], and others.

In the CIS countries, the teaching of geometric problems and simple differential equations based on computer technologies was disclosed in the works of O.V. Zimina [15], Yu.M. Kolyagin [6], also, the methods of teaching topics on differential equations using special tasks.

In foreign countries, scientific studies of such scientists as A. Renier [9], J. Renzulli [10], J. Gilford [4], were carried out, devoted to the importance of using problematic tasks in the process of teaching mathematics [ 7]. 


\section{THEORY AND DISCUSSION}

The theoretical significance of the study lies in the fact that it proposes a solution to the urgent scientific problem of creating the creative competence of future teachers. The research results make a certain contribution to the theory and methodology of teaching mathematics due to the fact that:

- the pedagogical essence is substantiated and disclosed, and a meaningful content of the concept "creative competence of the future teacher" is given based on a systematic analysis of the main provisions of the competency-based approach, the requirements of the Professional Standard of the teacher and the requirements of the Federal State Educational Standard of the educational direction of Pedagogical Education. It is established that creative competence is an important component of the professional competence of the teacher, and its formation is possible in the process of teaching mathematics at a university;

- the concept of "creatively-oriented mathematical tasks" was introduced as tasks modeling non-standard mathematical, life or professional situations in the language of mathematics, containing explicitly or implicitly the requirements to use mathematical methods of solving the problem, implying the implementation of creative activity;

- a significant contradiction has been revealed between the requirements of the labor market for modern highly qualified teachers who are ready to carry out creative activities using the mathematical apparatus and the currently insufficient orientation of the system of teaching mathematics of future teachers to the formation of their creative competence;

- studied the causal relationship between the implementation of the methodology for the formation of creative competence of future teachers in the process of teaching mathematics using a specially developed complex of creatively-oriented mathematical tasks and the dynamics of the level of formation of this competency;

- the process of the formation of creative competence of future teachers in the process of teaching mathematics was modernized on the basis of the developed methodological model, the structure of which has four stages: preparatory, input, formative, analytical.

The reliability and validity of the research results is determined by the following:

- for experimental work, reproducibility of the research results for various groups of respondents is shown;

- The theory is built on the basis of a systematic, activity-based, competency-based, personality-oriented approach, based on the basic theoretical and methodological principles of the formation of students' creative competence;

- used research methods that are adequate to the goals, objectives, subject of research;

- the idea of creating the creative competence of future teachers in the context of teaching mathematics using creatively-oriented mathematical tasks is based on the results of the analysis of state documents that determine the modernization of general and professional education, on the generalization of the best practices of specialists in the field of teacher training;

- in relation to the problems of the dissertation, the basic research methods (general theoretical, empirical, forming) of the level of formation of the creative competence of future teachers in combination with the use of statistical research methods (ranking, quantitative processing, qualitative analysis of the results: Fisher's $\varphi$ criterion, Student's t-test, have been effectively used, Kolmogorov criterion).

The creative competence of the future teacher is an integrative dynamic personality quality, which manifests itself in the ability to find original solutions to known problems, identify new problems and find ways to solve them using mathematical methods. The main structural components of the creative competence of the future teacher are: motivational, cognitive, active, reflective.

The implementation of didactic (the selection in the target component of teaching mathematics of the goals of creating creative competence of future teachers, the use of methods and forms of teaching mathematics aimed at creating the creative competence of future teachers, the sequential complication of types of creative activity) and organizational and methodological (the implementation of differentiated teaching of mathematics, the use of life experience students in the educational process, building up subjective-subjective relationships between all and participants in the educational process) conditions in the training of future teachers of mathematics contributes to the formation of their creative competence. The main criteria for the level of development of creative competence of future teachers: motivational, cognitive, active, reflective; levels of formation: low, medium, high. A special complex of creatively-oriented mathematical tasks that meet the requirements of problematicity, focus on students getting new knowledge and gaining experience of conscious inclusion in creative activity, non-determinism of student actions when completing tasks, the significance of the result for the student, task orientation on the formation of one or more creative components competency is a means of forming and developing creative competency future teachers in teaching mathematics.

The four-stage methodological model of the formation of creative competence of future teachers in the process of teaching mathematics is focused on the positive dynamics of the level of formation of this competency; during its development, the principles of formation of creative competence were taken into account: the target component of the methodology for the formation of creative competence of future teachers complies with the social order, continuity, consistency and continuity, the interconnectedness of the components of creative competence of future teachers, consciousness and activity of students; general requirements for creating a model: inertia, simplicity and adequacy, as well as the principles of normativity and universality.

The methodology for the formation of creative competence of future teachers in the process of teaching mathematics is effective; its main components correspond to the developed methodological model:

1) target - reflects the target vector of the formation of creative competence of future teachers in the process of teaching mathematics; 
2) substantive - enriches the content of teaching mathematics of future teachers with creatively-oriented mathematical tasks at each stage of the implementation of the model;

3) organizational and procedural - it is a set of mutually appropriate methods, forms and teaching aids adequate to the goals and content of the training (methods: heuristic methods, case study method, project method, game technology, etc.; forms: various types of lectures, seminar, business game, independent work of students, etc.; means: teaching aids, methodological recommendations for studying a course at the students' choice, alternative forms of tasks, etc.);

4) diagnostic - developed taking into account the specifics of creative competence of the future teacher and provides reliable information about the dynamics of the level of its formation.

Based on the principles of competency-based, systematic, personality-oriented and activity-oriented approaches to teaching, the principles of competence-based teaching students of mathematics, the principles of the formation of creative competence of future teachers are formulated: compliance of the target component of the methodology of creating creative competence of future teachers with a social order, continuity, consistency and continuity, the interconnectedness of the components of creative competence of future teachers, consciously STI and active learners.

Didactic ones were identified (the goal of creating the creative competence of future teachers in the target component of teaching mathematics, the enrichment of the content of the mathematical preparation of future teachers with a complex of creatively-oriented mathematical tasks, the use of methods and forms of teaching mathematics aimed at creating the creative competence of future teachers, the sequential complication of types of creative activity) and organizational and methodological (the implementation of differentiated teaching of mathematics, use of students 'life experience in the educational process, building up subjective-subjective relationships between all participants in the educational process) conditions for the formation of the future teachers' QC in the process of teaching mathematics.

Based on the general requirements for the creation of models, the principles of normativity and universality, as well as the principles for the formation of creative competence of future teachers, a methodological model for the formation of this competency in the process of teaching mathematics is presented, based on the principles of the formation of this competency.

Based on these principles, the model presents four stages: preparatory (the content and structure of creative competence of the future teacher is determined, a complex of creatively-oriented mathematical tasks is developed that matches the structure and criteria for the formation of creative competence, and diagnostic tools to determine the level of formation of creative competence) input (establishing the level of creative competency that students have), formative (increasing the level of formation of the creative competence of future teachers in the process of teaching mathematics), analytical (reflexive analysis of the results, formulate the appropriate conclusions).

In accordance with the goals of creating creative competence of future teachers, the content of instruction is enriched with competence-oriented mathematical tasks that model non-standard mathematical, life or professional situations in the language of mathematics, containing explicitly or implicitly the requirements to use mathematical methods of solving the problem, implying the implementation of creative activity.

Based on an analysis of the requirements for the development of competence-oriented tasks of various authors, taking into account the above-described conditions for the formation of creative competence of future teachers and the content of the mathematical training of students of various profiles, the principles of developing creative-oriented mathematical tasks were highlighted.

Given the selected principles for the development of tasks, the basis of their classification in this study is the orientation of tasks to the formation (development) of one or another component of the creative competence of the future teacher (cognitive, motivational, active, reflective).

An example of tasks aimed at creating a cognitive component of creative competence in a future teacher (Russell's paradox): "Let us agree to call a set "ordinary" if it is not its own element. For example, the multitude of all people is "ordinary," since the multitude itself is not a person. An example of an "unusual" set is the set of all sets, since it is itself a set, and, therefore, is itself an element of its own."

1. Determine whether a set consisting only of all "ordinary" sets (the Russell set) is ordinary, that is, does it contain itself as an element?

2. Explain why this task is called a paradox?

3. What creative methods for solving mathematical problems can be used to resolve this paradox?

This task is offered to students when studying the topic "Sets and operations on them. The paradoxes of set theory. "

Based on the results of the discussion, students are invited to compose a conceptual cluster for the task. In particular, a conceptual cluster can be compiled, as well as the method of transition states of a problem.

Or, you can use the "mediaquest + " method [11]. Interactive method "mediaquest + " (media + web-quest + vitagenic information) based on optimizing the development of the qualities of media culture of students, web-quests (short and long-term web-quests) and vitagenic technologies (vitagenic experience and vitagenic information) with a personality-oriented education [eleven].

When answering the third question, it is also possible to invite future teachers to characterize the possibilities of using the previously studied creative methods to complete the task.

Thus, in the course of such tasks, future bachelors and teachers acquire knowledge about creative methods for solving mathematical problems, as well as about methods for the formation and development of creative competence, students using the mathematical apparatus.

An example of tasks aimed at creating a motivational component of creative competence for a future teacher: "To get to the right restaurant in an unfamiliar city, a person asked the way for three citizens who were waiting for a taxi. 
And here are some tips he heard: 1) go now along the right street; 2) at the next turn, do not choose the right street; 3) at the third turn do not turn on the left street. A passerby passing by told the man that only one piece of advice was true and that it was imperative to go through the streets of different directions. The man got into the restaurant he needed. What route did he take?"

When organizing class work on the assignment, students are asked the following questions:

1. Is it possible to present the prompts of citizens in the form of some mathematical object? (Possible routes are presented in the form of a graph).

2. Is it possible to use elements of graph theory to resolve non-standard situations that may arise in your educational or future professional activities?

Work on such tasks allows students to show the possibility of applying mathematical knowledge (in this case, graph theory) to solve non-standard life situations, that is, encourages him to carry out creative activities.

\section{EXPERIMENTAL RESULTS}

Pilot work was carried out at the National University of Uzbekistan and consisted of the following stages: search, ascertaining, forming and correcting (generalizing). The total number of students involved in the experimental work was 242 people. The level of formation of creative competence was measured using the created diagnostic complex: special tasks, questionnaires, and expert sheets.

Using quantitative processing of the results of students performing control and experimental groups of tasks of input and final control, a distribution of students by the level of formation of creative competence at the beginning and end of each sub-stage of the forming experiment was obtained. It was found that the difference between the average levels of creative competence and mathematical preparation (the formation of mathematical competence (MK)) of students in control and experimental groups is statistically insignificant at the beginning of the formative experiment.

To test the statistical significance of this difference, the following hypotheses were put forward at the end of the forming experiment: null hypothesis $\mathrm{H} 0: 1 \mathrm{x}=2 \mathrm{x}$; alternative $\mathrm{H} 1: 1 \mathrm{x} \neq 2 \mathrm{x} .1 \mathrm{x}$ is the average level of creative competence of students of experimental groups and $2 \mathrm{x}$ is the average expected level of creative competence of students of control groups. At the significance level $\alpha=0.10$, the null hypothesis was rejected and the alternative accepted. Therefore, the difference between the average levels of creative competence of students in the control and experimental groups is statistically significant at the level $\alpha=$ 0.10 at the end of the formative stage of the experiment, which confirms the effectiveness of the developed methodology for the formation of creative competence of future teachers in the process of teaching mathematics.

To conduct a component-wise analysis of the formation of the components of creative competence of future teachers, empirical data were presented in table form.

Table 1. Dynamics of the level of formation of students' creative competence at the beginning and end of the forming experiment

\begin{tabular}{|c|c|c|c|c|c|c|c|}
\hline \multirow{3}{*}{$\begin{array}{c}\text { Groups } \\
\text { Number of respondents }\end{array}$} & \multirow{3}{*}{$\begin{array}{l}\text { Arithmetic } \\
\text { expression }\end{array}$} & \multicolumn{6}{|c|}{ Level indicators } \\
\hline & & \multicolumn{3}{|c|}{ At the beginning } & \multicolumn{3}{|c|}{ In the end } \\
\hline & & High & Middle & Low & High & Middle & Low \\
\hline $\begin{array}{l}\text { Experimental group } \\
n_{i}=122\end{array}$ & $\mathrm{X}_{\mathrm{i}}$ & 21 & 36 & 65 & 34 & 59 & 29 \\
\hline $\begin{array}{l}\text { Control group } \\
n_{\mathrm{i}}=120\end{array}$ & $\mathrm{Y}_{\mathrm{j}}$ & 20 & 37 & 63 & 24 & 41 & 55 \\
\hline
\end{tabular}

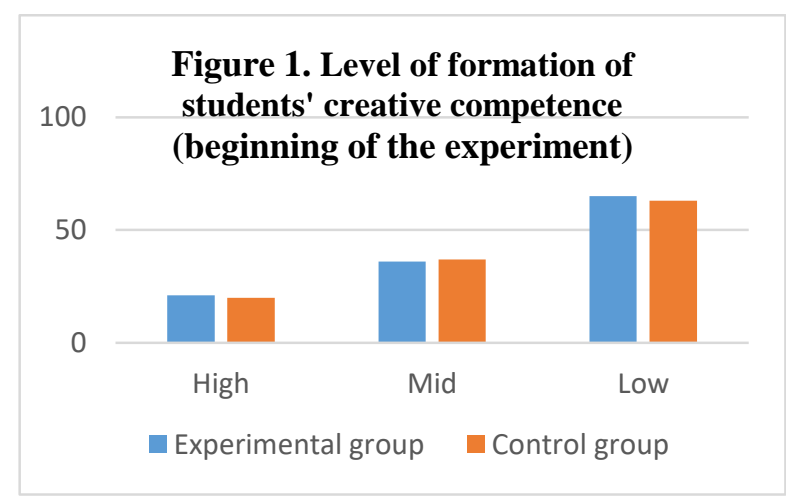

Thus, the effectiveness of the developed methodology for the formation of creative competence of the future teacher in the process of teaching mathematics has been experimentally confirmed. 
Also, an increase in the level of formation of mathematical competence among students of the experimental group was noted. Based on this, a hypothesis was put forward on the statistical significance of this difference, which was confirmed. The presence of a direct relationship of average strength on the Shaddock scale between the distributions of the number of students of experimental groups at the end of the forming experiment by the levels of mathematical and creative competence indicates that the development of creative competence of future teachers will contribute to the development of their mathematical competence.

\section{RECOMMENDATION AND CONCLUSION}

The concept of creative competence of future teachers as an integrative dynamic personality quality is clarified, which manifests itself in the ability to find original solutions to known problems, identify new problems and find solutions using mathematical methods.

The role of mathematical education at the present stage of development of society, as well as the potential content of mathematical disciplines for the formation of creative competence of future teachers are revealed.

The universal structure of creative competence of future teachers, which is independent of the profile of training and includes four components: cognitive, motivational, active, reflective, is defined and described, and the taxonomy of the levels of formation of components of creative competence (low, medium, high) is described. For evaluation, a rating scale of 2 to 5 points is introduced.

Didactic ones were identified (the goal of creating the creative competence of future teachers in the target component of teaching mathematics, the enrichment of the content of the mathematical preparation of future teachers with a complex of creatively-oriented mathematical tasks, the use of methods and forms of teaching mathematics aimed at creating the creative competence of future teachers, the sequential complication of types of creative activity) and organizational and methodological (the implementation of differentiated teaching of mathematics, use of students' life experience in the educational process, building up subjective-subjective relations between all participants in the educational process) conditions for the formation of creative competence of future teachers in the process of teaching mathematics. The forms and methods of teaching aimed at the formation of students' experience in creative activities in the classroom and extracurricular (independent) work of students are determined.

A methodological model for the formation of creative competence of future teachers has been created, based on the principles of integrativity, simplicity, adequacy, universality, normativity, consistency and didactic principles for the formation of creative competence of future teachers (matching the target component of the methodology of creating creative competence of future teachers with a social order, continuity , consistency and continuity, interconnectedness of components of creative competence of future teachers, consciousness and activity of students).

The methodology for the formation of the CC of future teachers in the process of teaching mathematics was developed and tested on the basis of a special set of tasks:
- the goals and objectives of teaching mathematics aimed at the formation of QC are defined: awakening students' interest in the implementation of mathematical activity in solving professional problems; students learning the basics of mathematical methods of information processing, a creative approach to analysis, systematization of information, presentation of results; independent search by students of ways and options for creative solutions to the problem (mathematical or pedagogical); students transferring their existing experience in solving mathematical problems to solving the problems of their training profile (mathematical modeling); the formation in students of the experience of creative activity in solving mathematical problems, etc.;

- The forms and methods of organization of teaching mathematics were determined, aimed at creating the creative competence of future teachers;

- a complex of creatively-oriented mathematical tasks has been developed, which allows to form creative competence of future teachers in the process of teaching mathematics;

- created a diagnostic complex to determine and evaluate the level of formation of creative competence of future teachers.

The effectiveness of the methodology for the formation of the CC of future teachers in the process of teaching mathematics on the basis of a special set of tasks is confirmed.

\section{REFERENCES}

1. Abdullayeva B.C. Fanlararo aloqadorlikning metodologik-didaktik asoslari (Ijtimoiy-gumanitar yonalishlardagi akademik litseylarda matematika oqitish misolida): ped. fan. dokt. diss.avtoref., Tashkent, 2006, pp44-49.

2. Alixonov S. «Matematika oqitish metodikasi», Tashkent, 1992, pp.146-200.

3. Gaybullayev, N.R. Dirchenko I.I. Razvitiye matematicheskix sposobnostey uchashixsya: Metodicheskoye posobiye dlya uchiteley / N.R. Gaybullayev, I.I.DirchenkoT.: Oqituvchi, 1988, pp. 114-248.

4. Gilford Dj. Tri storoni intellekta//Psixologiya mishleniya: sb. perevodov/pod red. A.M.Matyushkina.-Mocow, Progress, 1965, pp. 433-456.

5. Ikromov J. "Maktab matematika tili”. - Tashkent: Oqituvchi, 1977, pp.163-195.

6. Kolyagin Yu.M., Oganesyan V.A. Uchis reshat zadachi. // Posobiye dlya uchashixsya 7-8 klassov. -Moscow, Prosvesheniye, 1980, pp. 96-105.

7. Makhmudova D.M. Use of problem tasks in development of independent creative activity of students. International Journal of Innovative Technology and Exploring Engineering (IJITEE), ISSN: 2278-3075, Volume-IX, Issue-II, December 2019.

8. Mamatov M.Sh. Maktab matematika kursida mantiq va intuitsiya uyg'unligi// Xalq talimi.-Tashkent.2003, Volume № 5, pp. 120-124.

9. Renier A. Dialogi o matematike.-Moscow, Mir, 1980, pp 300-376, chapter "V mire nauki i texniki".

10.Renzulli Dj.S., Ris M. Model obogashayushego shkolnogo obucheniya: prakticheskaya programma stimulirovaniya odarennosti detey // Osnovnie sovremennie konsepsii tvorchestva i odarennosti. - Moscow, Molodaya gvardiya, 1997, pp 312-37.

11.Rustamova N.R. The Technology of Developing Media Culture in Secondary School Students. International Journal of Innovative Technology and Exploring Engineering (IJITEE), ISSN: 2278-3075, Volume-IX, Issue-II, December 2019.

12.Tulaganov T. Matematika oqitish metodikasi (ma'ruzalar toplami), TDPU, 2011.

13.Uzbekiston Respublikasi Prezidentining 2017 yil 7 fevraldagi PF-4947 son "Uzbekiston Respublikasini yanada rivojlantirish bo'yicha Harakatlar strategiyasi tugrisida"gi Farmoni. Aviable: www.lex.uz. 
14.Yunusova D.I. Matematikani o'qitishning zamonaviy texnologiyalari, Tashkent, Fan va texnologiyalar, 2011, pp. 122-200.

15.Zimina O.V. Problemnoye obucheniye visshey matematiki v texnicheskix vuzax//Matematika v visshem obrazovanii.Moskva, 2006. Volume №4, pp.55-77.

16.Zlotskiy G.V. O psixologo-pedagogicheskoy i metodiko-matematicheskoy podgotovke studentov matematikov universitetov k professionalno-pedagogicheskoy deyatelnosti. //Ta'lim muammolari. - Tashkent, 2000, Volume №2, pp.28-30.

\section{AUTHORS PROFILE}

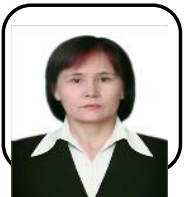

Makhmudova Dilfuza Melievna obtained her Bachelors and Master's Degree in Mechanics \& Mathematics from The Tashkent State University. She received her Ph.D degree from from National university of Uzbekistan, Uzbekistan, 2017. She has published more than 30 Journals and 23 papers in both national and international conferences.

Rustamova Nodira Rustamovna obtained her Bachelors and Master's Degree in Professional Education \& Cultural Science from The Tashkent State Institute of Culture named after Abdulla Kadyri. She received her Ph.D. degree from Tashkent State Pedagogical University named after Nizami, Tashkent city, Uzbekistan, 2019. She has published more than 21 Journals and 19 papers in both national and international conferences.

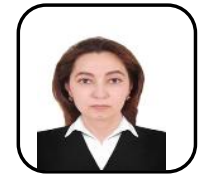

Akbarova Nigora Alimdjanovna obtained he Bachelors and Master's Degree in Physics from The Tashkent State University. She received her Ph.D degree from National university of Uzbekistan, Uzbekistan, 2018. She has published more than 10 Journals and 11 papers in both national and international conferences.

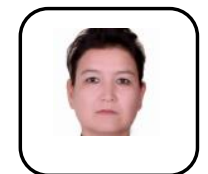

Reymbaeva Sanabar Rejepbaevna obtained her Bachelors and Master's Degree Physics from The Tashkent State University. She has published 3 Journals and 5 papers in both national and international conferences. 